\title{
ONLINE HABITS OF THE 55 PLUS GENERATION IN A SELECTED REGION OF THE CZECH REPUBLIC
}

\section{ONLINE NAVIKE GENERACIJE OD 55 I VIŠE GODINA U IZABRANIM REGIJAMA REPUBLIKE ČEŠKE}

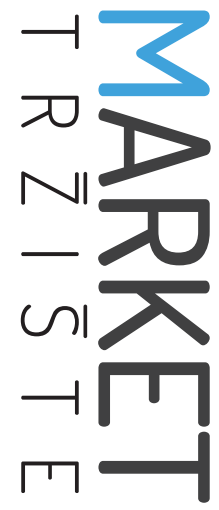

\author{
Market-Tržište \\ Vol. 29, №. 2, 2017, pp. 125-138 \\ UDK 004.738.5-053.9(437.1/.2) \\ DOI http://dx.doi.org/10.22598/mt/2017.29.2.125 \\ Preliminary communication
}

\section{Čeněk Celer ${ }^{a}$, Michaela Jánskáb}

a) Faculty of Social and Economic Studies, Moskevská 54, Ústí nad Labem, CZECH REPUBLIC, cenek.celer@ujep.cZ

b) Faculty of Social and Economic Studies, Moskevská 54, Ústí nad Labem, CZECH REPUBLIC, michaela.janska@ujep.cz

\begin{abstract}
Purpose - The Internet is now becoming part of the 55 and up generation. This study assumes that there is an increasing number of elderly people using the Internet. Based on this assumption, this article's objective is to explore the impact of selected demographic characteristics on Internet usage variables. These variables include the frequency of the Internet use, the Internet access location, the type of information sought, and the overall frequency of use of this media for a particular purpose.
\end{abstract}

Design/Methodology/Approach - The introduction presents the theoretical background of the topic and is followed by a section focusing on the evaluation of primary research data. This data includes the use of a correlation coefficient that measures the level of dependence between the variables studied. Another tool used during research is called a decision tree. A decision tree detects the variable with the strongest influence on the Internet use. In this case, the variable was the location used to access the Internet.

Findings and implications - When examining the conditionality between demographic variables and the Internet use, we are talking about independence or, more precisely, a slight dependence. This has to do with the fact that seniors of all ages use the Internet regardless of demographic factors. It is more about social influences.

\section{Sažetak}

Svrha - Internet postaje dio života generacije od 55 i više godina. Istraživanje pretpostavlja da sve više raste broj starijih osoba koje koriste internet. Na temelju ove pretpostavke, cilj je rada istražiti utjecaj izabranih demografskih obilježja na varijable korištenja interneta. Te varijable uključuju učestalost korištenja interneta, mjesto pristupa internetu, vrstu traženih informacija te ukupnu učestalost korištenja ovog medija za određenu svrhu.

Metodološki pristup - Uvod predstavlja teorijsku pozadinu teme, a slijedi ga dio rada koji je usredotočen na procjenu podataka prikupljenih primarnim istraživanjem. Ti podaci uključuju korištenje koeficijenta korelacije koji mjeri razinu zavisnosti između promatranih varijabli. Drugi alat koji se koristi tijekom istraživanja naziva se stablo odlučivanja. Ono otkriva varijablu s najjačim utjecajem na korištenje interneta. U ovom slučaju to je bila varijabla lokacija s koje se pristupa internetu.

Rezultati i implikacije - Pri ispitivanju uvjetovanosti između demografskih varijabli i korištenja interneta, govori se o nezavisnosti ili preciznije, neznatnoj zavisnosti. To se odnosi na činjenicu da starije osobe svih dobi koriste internet bez obzira na demografska obilježja. To je više uvjetovano društvenim utjecajima.

Ograničenja - Podatke dobivene ovom analizom nije moguće primijeniti na cijelu Republiku Češku. 
Limitations - It is not possible to take the data found in this analysis and apply it to the Czech Republic as a whole.

Originality - Based on the research results, we can refute any significant impact of demographic characteristics on the Internet use by seniors. The discourse describes and subsequently compares the views of both foreign and domestic research on the issue.

Keywords - Internet, older people, demographic characteristics, Internet usage variables, Czech Republic, decision tree
Doprinos - Na temelju rezultata istraživanja može se odbaciti bilo kakav značajan utjecaj demografskih obilježja na to da starije osobe koriste internet. Diskurs opisuje i kasnije uspoređuje poglede i stranih i domaćih istraživanja o tom pitanju.

Ključne riječi - internet, starije osobe, demografska obilježja, varijable korištenja interneta, Republika Češka, stablo odlučivanja 


\section{INTRODUCTION}

It is obvious that the elderly do not constitute a homogenous group. Their characteristics are as diverse as are those of the entire population. Nevertheless, this group is often described as a group with declining mental and physical abilities (Twigg, 2004). While this assumption may be partly justified, it is clear that, regardless of increasing age, most seniors remain active and productive. Authors Katz and Marshall (2003) and Westerhof, Harnik, Van Selm, Strick and Van Baaren (2010) indicate in their publications that the age of retirement is often seen as an opportunity to take up new activities and to engage in new educational and employment opportunities. This presents a favorable youthful image of the older people who are active, healthy, and independent.

The definitions of "older people" differ depending on the author. Based on the definitions used by the United Nations and the World Health Organisation, "older persons" are those who are older than 60. According to Čsú, the elderly population group begins at the age of 65 . Marketing studies indicate that it is not necessary to address individuals at the age of 50 any differently in marketing communications (Clow \& Baack, 2008). The Czech author Dvořáková (2007) divides older persons into three groups. The first is made up of the so-called "pre-pensioners" (50-62 years old); these people are actively involved in the labor market and have therefore become a target group for merchants. Marketing professionals are currently trying to acquire this group to generate income. The second group consists of "active pensioners" (63-74 years old), who are still able to work. However, they follow their budgets and have become interested in maintaining their health. Marketing professionals are not very interested in this group. The third group is considered to consist of "truly elderly persons" (above 75 years old), who prefer taking care of their health conditions and being with their families than actively shopping (Sak \& Kolesárová, 2012).
In terms of the impact of marketing tools, it is necessary to perceive older persons based on the period in which they developed their value system. Currently, elderly people aged 80 and up spent most of their active life in a totalitarian state, so it may be assumed that the majority of them developed their values during that period. It also possible to assume that values important to people who are 20 years younger (i.e. those aged 60) could have changed during the years of the democratic regime.

Our information-rich society believes that it is necessary to support the older generation in order for them to live independently and to enjoy a high quality of life. This goal can be achieved thanks to the use of information technology that can help elderly people overcome isolation and loneliness while also increase the possibilities for them to keep in touch with friends (EU, 2011). The use of computer communication and online interactions enrich their social lives as they can engage in topics that are of interest to them (Ogozalek, 1991).

The Internet, with its capabilities, is important to everyone but its actual contribution may depend upon the needs and the social position of the individual user. Although the Internet is relatively young, it has had a great impact on society because it can overcome the constraints of time and space. It provides isolated people with the opportunity to communicate through social networks and to create various virtual communities of a communicative, informative or entertaining nature (Lin, 2006; Wright, 2000). The proportion of households, in EU countries, that use the Internet is on the rise; in 2012, $72 \%$ of users had access to the Internet. The Czech Republic recorded a significant increase in Internet use of more than $30 \%$ between the years 2008 and 2012. In 2008, $46 \%$ of Czech households used the Internet while their portion rose to $71 \%$ by 2011 (Seybert, 2012). In addition to these findings, a 2014 Eurostat study found that everyday Internet use had increased to $65 \%$ that year from $41 \%$ in 2006 (Eurostat, 2015). 


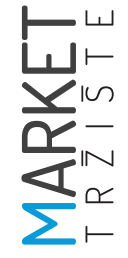

\subsection{Previous research of the topic}

Until 1990s, the majority of older people were indifferent to information technologies, including the use of personal computers and Internet access, but their interest is currently growing (Grimes, 2010). The ability to use the Internet is an important factor in the lives of $50+$ users which is affected by their age, sensory and cognitive changes (Hanson, 2010). The number of seniors using the Internet has been growing gradually since 1999, as evidenced by the research of the Pew Research Center, which noted a sharp global increase in Internet use among the elderly in 2000 and again in 2004 (Ruggiero, 2000; Australian Bureau of Statistics, 2004; Fox, 2004). An Australian study shows that the largest increase in Internet usage was among seniors aged 55-64, from $63 \%$ in 2009 to $71 \%$ in 2011 (Ryan, 2013). This fact was also confirmed by research carried out in 2010 by the British company Ofcom (2010), revealing that $69 \%$ of people in the 55-64 age group connect to the Internet; in the 65-74 age group the number of those who connect dropped to $51 \%$ and in the $75+$ group less than a quarter ( $23 \%$ ) of respondents were online. The use of the Internet by the older population has had a similar tendency in the U.S. In 2014, $47 \%$ of people 65 and older reported having broadband Internet access at home. In 2012, that figure was $39 \%$ and in 2008 only $19 \%$ (Smith, 2014). The results of our research show that seniors use the Internet mainly at home and, within the 55-65 age group, both at work and at home. Only a few seniors use the Internet solely at work. These results coincide with the research paper by Čevela, Čeledová, Kalvach, Holčík and Kubů (2014).

According to research by Clark (2002), White and others (2002), Shapira, Barak and Gal (2007), Sum, Mathews, Hughes and Campbell (2008), and Saboor, Sum, Sahaf, Sahaf and Pourghasem (2015), seniors prefer the Internet in communication - mainly to search for information, for entertainment, but also for shopping and making new social contacts. In their study carried out in Australia, Russell, Campbell and Hughes
(2008) stated that most seniors use the communication and information properties of the Internet mainly to keep in touch with their families, friends, and the wider public via social networks. This information has been confirmed by Bosch and Currin (2015). In their study, they claim that seniors over 65 years of age usually seek general information by using the Google search engine. Eurostat data (2015) confirm that people in the 55-74 age group use the Internet mainly to read news. Apart from communicating via e-mail, most Internet users in the 55-74 age group look for information about goods and services or read online news. By contrast, people the 16-24 age group more often communicate via social media, listen to the Internet radio and watch the Internet television and movies, play games and download them from the web, in addition to searching for information about goods and reading news online (Seybert, 2012).

A 2008 study by the American authors Gatto and Tak (2008) indicated that $55 \%$ of seniors come into contact with the Internet on a daily basis. Of that, $8.6 \%$ connects to the Internet 3-4 times per week and $15.5 \%$ use the Internet once per week. In 2012, Eurostat indicated that $42 \%$ of the EU population aged 55-74 old connected to the Internet at least once per week — which is less often than among younger people (Seybert, 2012).

\section{METHODOLOGY}

The European population is growing older and so is the population of the Czech Republic. According to data provided by the World Health Organisation in 2014, the proportion of the world's population over the age of 60 will double from about $11 \%$ to $22 \%$ between 2000 and 2050. The absolute number of people aged 60 and older is expected to increase from 605 million to 2 billion over the same period (World Health Organisation, 2014). Statistics clearly show that growth in the number of older people should not be ignored. Eurostat's population projection estimates that, by the year 2060, 
there will be fewer than two people of the productive age (15-64 years) per each person aged 65 and older. The current ratio is 4:1 (European Commission, 2011a; 2011b).

The percentage of older people using the Internet has increased substantially in recent years, which is also assumed in this study. Based on this assumption, the aim of the article was to analyze the use of the Internet by people 55 years old and up, in terms of selected demographic characteristics. We have been inspired by the division into age groups in different studies and by the fact that people aged $55+$ had no active interaction with any computing technology in their early years (Śniadek, 2006; Westerhof, Barrett \& Steverink, 2003; Ward, 2013).

Firstly, the variables were defined based on the location of access, frequency, and success of Internet use, as well as the nature of the information sought-after. This information was then examined in relation to the age group of older people, their social status, education, and their connection to the people in their household. The Internet use success rate is defined by the share of successful searches for information on the Internet. Based on these variables, an assumption was made that the level of education attained by the respondents and their status had no bearing on the type of information obtained from the Internet. The second objective was to determine whether there was a correlation between the frequency of Internet usage for a particular purpose (entertainment, education, information searches, and communication) and the age of the respondents.

In order to fulfill the objectives of the work, information from secondary and primary sources was used. The secondary information was gathered primarily from literature and from foreign papers by a number of different authors. The primary data collection was obtained by means of written questionnaires, which were used in order to determine the extent to which the selected target groups use the Internet. The Usti Region of the Czech Republic was the specific location of the data collected because of its ranking as the second region by the low number of $65+$ seniors (17.1\%). The statistical data also shows that the Usti Region occupies the sixth position according to the number of live births per 1000 inhabitants. But, on the other hand, it has the second highest mortality rate in the country (Demografické charakteristiky populace seniorů, 2015; Charakteristika Kraje, 2015). The reason for acquiring data at the local level was that it provided an opportunity to update information in order to adapt to the requirements of a specific area. On the other hand, it demonstrates that information from a specific region can influence other regions.

The answers obtained from the respondents were divided up based on an analytical classification, which allowed us to examine the relationships and dependencies between the findings by determining the absolute frequencies, correlation, association, and decision trees. Two programs - Microsoft Excel spreadsheet and IBM SPSS STATISTICS 23 program for statistical data analysis - were used for data analysis.

\section{RESULTS}

A total of 603 older persons took part in the survey. In order to compare the communication behavior between the age groups with respect to their employment status, the respondents were divided into four categories based on their age: $55-60,61-66,67-74$, and 75 and older. Of the 603 respondents surveyed, a total of 337 were found to use the Internet (i.e. $57 \%$ of the older persons surveyed). Some $61 \%$ of men and more than a half of the women among the respondents said that they use the Internet; its use was most widespread by the respondents who are $55-60$ years old (86\% of respondents in that age group).

In the group of respondents aged 61-66, the Internet is used by $69 \%$ of them. More than a half of 67-74 year old respondents use this medium. However, in the category made up of the oldest respondents, the Internet use falls to $20 \%$ (i.e. every fifth respondent in the age group of aged 
$75+$ year olds uses the Internet). Figure 1 shows the structure of Internet users according to their social status. A total of $57 \%$ of users come into contact with the Internet on a daily basis, $28 \%$ of them use the Internet 2-4 times a week, $10 \%$ use it once a week, and $5 \%$ of them use it once a month.

\section{FIGURE 1: Social status of Internet users}

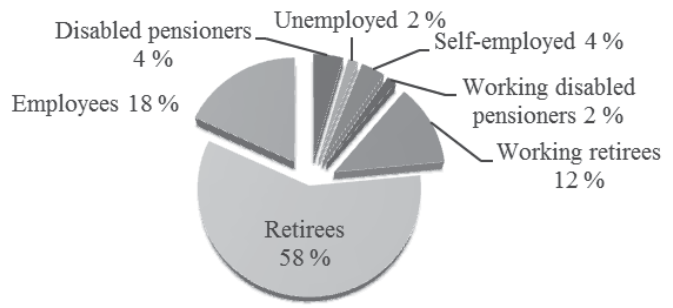

Source: authors' own work

The respondents not using the Internet are primarily old-age pensioners aged 67+ (a total of $74 \%$ of respondents). They say that they do not use the Internet at all. Only $8 \%$ of respondents aged 55-60 years did not use the Internet. These included, in particular, the respondents labeled as disabled (old-age) pensioners or the unemployed.

\subsection{Place of Internet use}

A home Internet connection was available to almost $95 \%$ of the Internet users surveyed and to every working disabled pensioner, as well as to $97 \%$ of working retirees, and to $86 \%$ of the un- employed. In the category of 55-60 year olds, $98 \%$ of Internet users have a suitable connection at home; with increasing age, the proportion of households with an Internet connection declines slightly to $94 \%$ in the oldest category of $75+$. Almost $90 \%$ of single users connect to the Internet at home, as well as $95 \%$ of those who live in a household with a partner and those who live with their children. The surveyed respondents living in homes for the elderly have no connection.

More than two-thirds of users use the Internet primarily at home, more than a fifth at work, $11 \%$ at a relatives' or neighbors' home, and only one percent use it in a coffee shop or library. As many as $92 \%$ of disabled pensioners, as well as $88 \%$ of working disabled pensioners, and four-fifths of retirees use the Internet at home; however, this is where it is least used by half of the employed and by more than a half of the working retirees.

\subsection{Types of information sought}

Two thirds of the respondents use the Internet mostly to read the news about current social, economic and political events; $8 \%$ of these are mainly interested in travel and accommodation, the same percentage are mainly interested in goods and services, and $7 \%$ each in health and information related to their profession or education. Only $3 \%$ of surveyed seniors look for information about culture. Men seek out news and updates on politics more often (71 \%) than do women (63\%); on the other hand, women

FIGURE 2: Searched information, in percentage terms

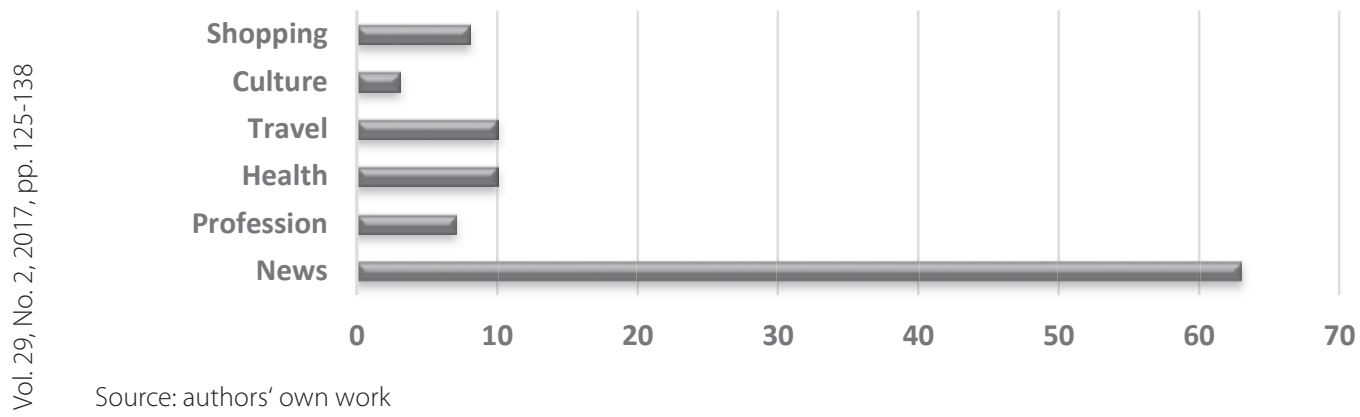


are more concerned with health $(10 \%)$ than are men (3 \%). Information about travel or accommodation is more often sought out by women $(10 \%)$ than men (only $6 \%$ ). Men are more interested in the news, education and their profession. Meanwhile, an identical percentage $8 \%$ - of women and men look for information about products and services.

Figure 2 provides a general overview of the information that seniors search for on the Internet.

Two-thirds of Internet users seek out useful information using the Seznam search engine, less than $30 \%$ use Google, with $5 \%$ using Centrum and only one respondent saying he uses Atlas. The seniors surveyed do not use other kinds of search engines. This data is also confirmed by studies published by Efectix and TopList, which found Seznam and Google to be the most widely used search engines in the Czech Republic (TopList, 2017). The Seznam search engine is the most popular among seniors over 67 years of age, disabled pensioners and working pensioners, whereas the Centrum search engine is most popular among respondents belonging to the unemployed and self-employed segments. Recent surveys of the Czech online market indicate a growing popularity in the use of Google as a search engine (StatCounter, 2017).

Our survey showed $15 \%$ of the respondents admitting that they find everything online, with more than a half usually finding what they need and a quarter of them saying that they are successful in $50 \%$ of cases. Only $3 \%$ of seniors admitted that they cannot usually find the information they want, and $4 \%$ do not know how to search online. These are mainly truly elderly retirees. Of all age groups, seniors in the segment of 55-60 year olds are the most successful in their searches, but the success rate decreases with increasing age. Internet searches are easier for women, respondents with a higher or secondary education, the self-employed and disabled pensioners.

\subsection{Frequency of Internet use for a particular purpose}

The research results show a quarter of respondents searching for news, information about legislation, or using online dictionaries almost every day. One-fifth of them do so a few times per month, and the same proportion - one-fifth - once per month and never, while $14 \%$ seeks similar information twice a week. While men more often search for news, a quarter of women never read the news. Nearly $60 \%$ of self-employed respondents, $30 \%$ of those employed and only one percentage point less of unemployed respondents seek this kind of information almost every day. Two-fifths of disabled pensioners and more than a quarter of retirees do not search such information on the Internet at all. The frequency of searches for news decreases with the increasing age of the respondents. In the youngest segment (55-60 years), almost $30 \%$ of the respondents look at the news about current political and social events every day; in the 67-74 years segment the frequency is lower at every fifth, but in the oldest segment (75+) it drops down to every fourth senior. Such information is never sought by a quarter of the respondents aged 61 years and older.

Nearly a half of the respondents with the university-level education looks at the news almost daily, $15 \%$ twice do it per week, one-fifth several times per month, $6 \%$ once per month and $11 \%$ do not feel the need to look up such information. One-fifth of the college-educated seniors browse the Internet for the reasons mentioned above almost daily, the same number never does it or resorts to the Internet just once per month, and a quarter of them does it several times per month. More than one-third of the respondents with primary education do not seek such information at all, a quarter of them seek it once per month, and $14 \%$ do so almost every day, twice per week or several times per month each. Some $43 \%$ of the respondents who live with children seek the news almost daily, as do more than a fifth of the respondents who share a household with a partner, and of single se- 


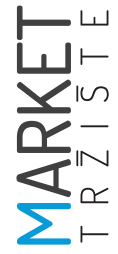

niors. A quarter of the seniors living alone and more than a fifth of those living with a partner do not look up such information at all.

A fifth of the respondents search for entertainment online almost every day, the same proportion do it twice per week or once per month, while a quarter of users never use the Internet for entertainment. When it comes to the frequency of use of this medium for entertainment, there is not much difference between men and women. Figure 3 shows how often seniors use the Internet for entertainment based on their age and social status. It indicates that the frequency of Internet use for entertainment and leisure decreases with the increasing age of seniors. often, it is used for entertainment by single seniors (23\%), slightly less often by the respondents who live with a partner (one-fifth) and least by the respondents who share a household with their children (16\%). Of these, one in four seniors does not need the Internet for entertainment.

An equal number of men and women surveyed, or $30 \%$, said they do not use the Internet for educational purposes at all. Only $7 \%$ of men and $3 \%$ of women are being educated through this medium on a daily basis, $13 \%$ of both sexes twice per week, a quarter of women and a fifth of men a few times per month, and almost $30 \%$ of members of both sexes once per month. Some $43 \%$ of the unemployed, $36 \%$

FIGURE 3: Frequency of Internet use for entertainment based on age and social status, in percentage terms

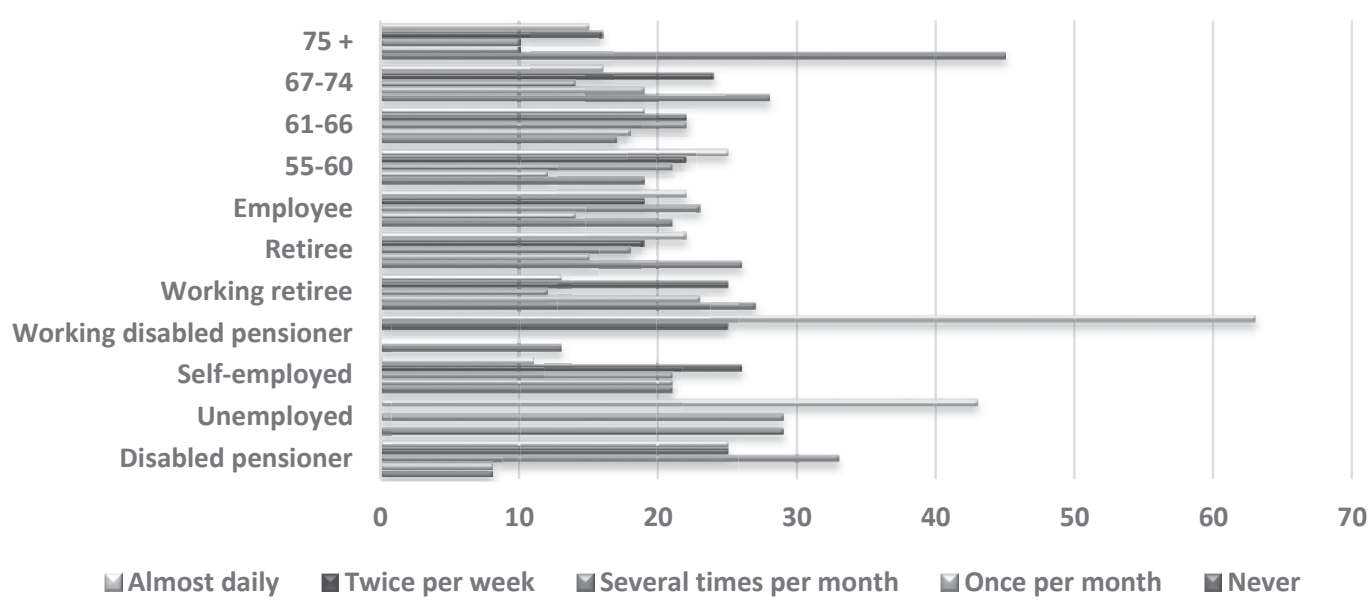

Source: authors' own work

The frequency of Internet use for entertainment drops with the increase in the level of education. This form of distraction is pursued daily by more than a quarter of the respondents with primary education, by one-fifth of high school graduates, and by only $15 \%$ of university graduates. One-fifth of seniors with primary education never use the Internet for entertainment, compared to $23 \%$ of those with secondary education and $30 \%$ of university graduates. Most of retirees, a quarter of working disabled pensioners and working retirees, and a fifth of the self-employed do not seek out online information pertaining to education. By contrast, almost $30 \%$ of unemployed respondents use the Internet for training purposes almost daily, almost two-fifths of working disabled pensioners use it twice per week, a third of working retirees, a quarter of the self-employed, a quarter of employees and a fifth of retirees use it several times 
per month. Online information about education is looked up once per month by approximately $30 \%$ of the unemployed, self-employed, retirees, and employees, as well as by a quarter of the self-employed and retirees.

Respondents do not use the Internet to acquire new information and knowledge on a daily basis, but rather several times a week. Generally speaking, the level of intensity and consistency of the Internet use is related to the age of respondents. A total of $8 \%$ of the respondents aged $55-60$ years, $5 \%$ of the respondents in the 61-74 age group, and $3 \%$ of the respondents older than 75 connect to the Internet to acquire new information and knowledge on a daily basis. A total of $17 \%$ of respondents aged $55-60$ years, $10 \%$ of those aged $61-74$ years, and $8 \%$ of the respondents older than 75 years connect to the Internet for this purpose twice a week. Nearly a third of seniors with primary and secondary education and $17 \%$ of university graduates do not expand their knowledge online at all. This form of education is used on an almost daily basis by $13 \%$ of university graduates and $3 \%$ of respondents with lower education, of whom a third expands their knowledge online once per month. A third of the seniors living with a part- ner and $30 \%$ of those who live alone never use the Internet for education. Seniors who share a common household with their children appear to educate themselves the most in this manner: $9 \%$ of them do so daily, a fifth twice per week, $14 \%$ once per month, and $41 \%$ at least once per month.

More than a half of the Internet users surveyed, with equal distribution between men and women, do not visit e-shops. However, $30 \%$ do so once per month, $12 \%$ several times per month, $2 \%$ twice per week, and $1 \%$ almost daily. Regarding the distribution of segments based on the nature of households, the seniors who live with their children buy from e-shops most often: $16 \%$ several times per month and $43 \%$ once per month. Three quarters of the respondents with primary education level never search e-stores, $15 \%$ shop online once per month, and $6 \%$ once per month. A third of university graduates and high school graduates visit e-stores once per month, against $14 \%$ who do so several times per month. The frequency of Internet use for shopping by the elderly based on their age and social position is shown in Figure 4. It clearly indicates that the intensity of e-shopping decreases with increasing age.

FIGURE 4: Frequency of Internet use for purchases based on age and social status, in percentage terms

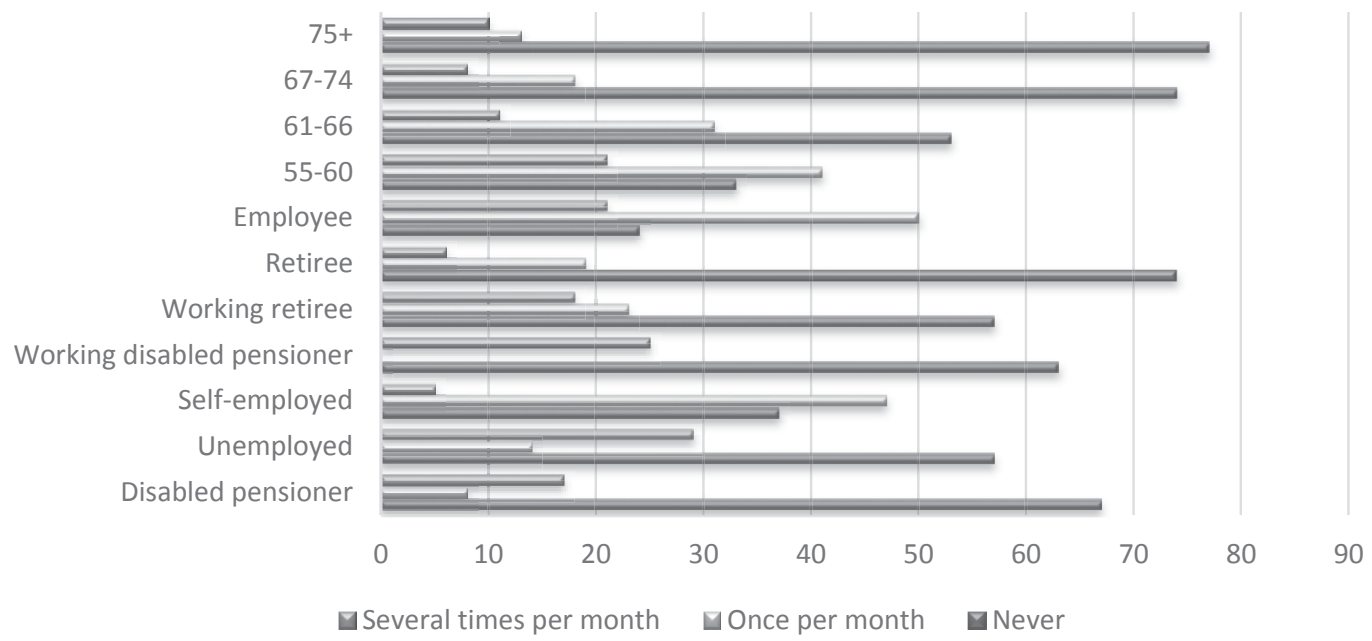


More than a fifth of seniors use the Internet to communicate (phone calls, chatting, etc.) almost daily, the same number uses it several times per month, $15 \%$ twice per week, while every tenth senior does it once per month. However, a third of the surveyed seniors do not communicate via the Internet at all. They include the unemployed - as many as $43 \%$ of them, a third each of working disabled pensioners, working retirees and retirees, but only $8 \%$ of disabled pensioners. These are the most active categories of seniors when it comes to communicating via the Internet: $42 \%$ of respondents living with a partner, a third of the unemployed, self-employed and employees, a third of university graduates, a quarter of working disabled pensioners, and disabled pensioners chat online almost daily.

The frequency of Internet communication decreases with the increasing age of seniors: while it is used on a daily basis by $31 \%$ of the respon- dents aged 55-60 and by a fifth of those in the 61-66 year segment, in the 67+ group it is only $12 \%$ of the respondents who do so, of whom one-fifth stated that they communicate only a few times per month. This method of using the Internet does not appeal to $42 \%$ of respondents older than 75 years. Seniors sharing a common household with their children communicate intensively: one-third does so almost daily, one tenth twice per week, the same proportion of the respondents in this category to communicate online several times per month, while $36 \%$ of them never resort to online communication.

\subsection{Utilization of a decision tree to analyze Internet use by older persons}

In determining which variable has the strongest influence on the Internet use, a decision tree model was utilized. In this model, $87 \%$ of cases

FIGURE 5: Decision tree analysis of the Internet use by older persons

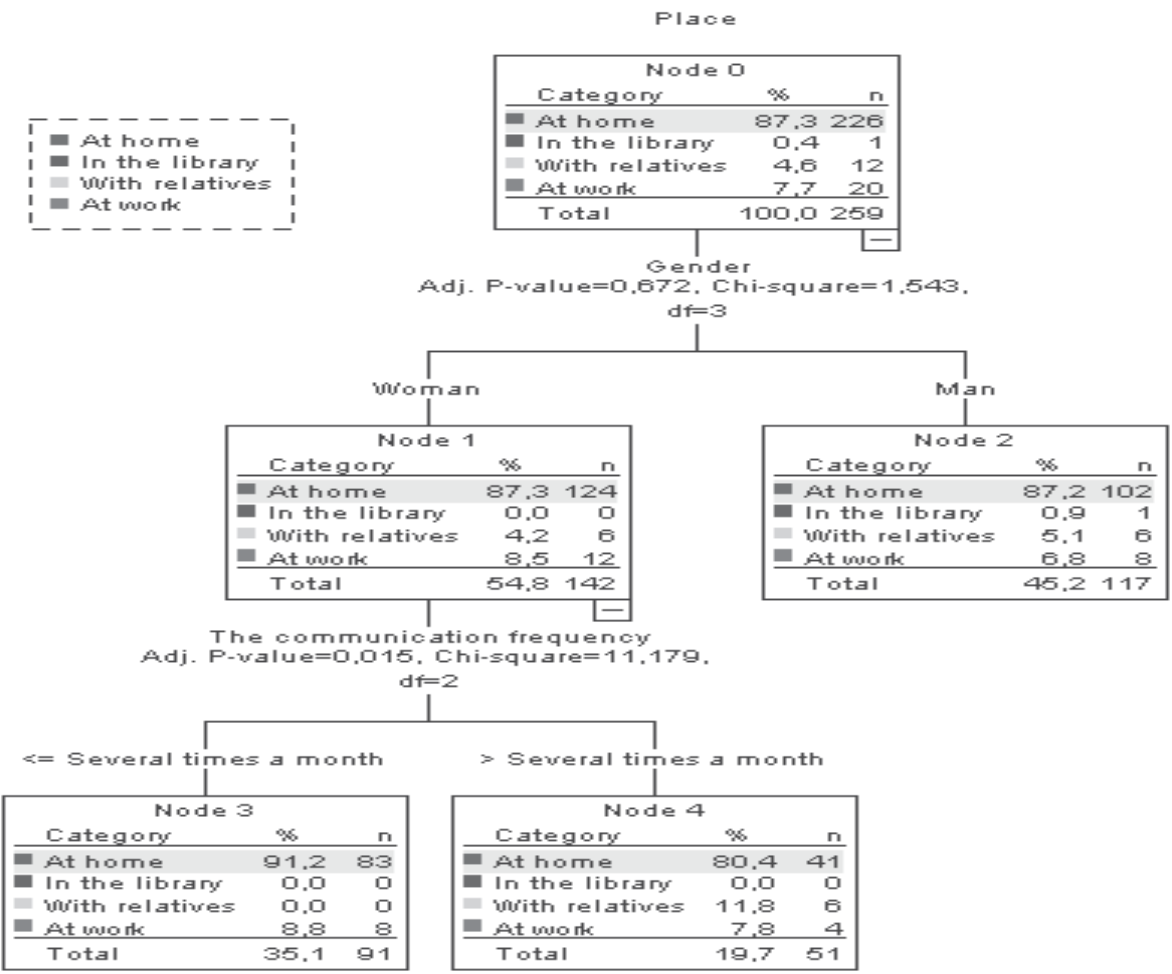

Source: authors' own work 
were correctly classified, which means that the error rate was $13 \%$. The locations at which the respondents connect to the Internet were used as the dependent variable, with demographic characteristics and the frequency of the Internet use for different purposes serving as the independent variables.

The gender of the respondent is the main predictor of the location of Internet use. Most women use the Internet at home (87\%), at work (8.6\%) or at their relatives (4.2\%). Men (1\%) use the Internet in the library more than do women, as women do not go to the library in order to use the Internet at all. For men this is the only predictor, for women the use of the Internet to communicate appears to be another significant predictor. On the basis of this criterion, women are divided into two groups according to the frequency of Internet use. The first group uses the Internet to communicate several times per month, mainly at home (91\%) and at work (9\%). The second group uses the Internet to communicate less than once per month, mainly at home (80\%), at work (8\%) and at their relatives (12\%). Based on Figure 5, it can be concluded that seniors use the Internet at home; men use it more often at the homes of their relatives, against women who do so at work. The purpose of the Internet use - that is, to communicate with other people, is also an important predictor for women. Interestingly, the women who communicate only a few times per month use the Internet not only at home but also at their relatives' home.

\subsection{Measuring the strength of correlation between variables}

The above data resulting from the survey were completed by making an assessment of the correlation between variables in the form of correlation analysis, which aims to compare the relationship between individual activities that affect the use of the Internet and the selected characteristics of the respondents - their age, education, social status and the number of members in the household. The association and correlation coefficients were calculated using the SPSS Statistics program, the nominal values were calculated with the help of the Cramer's V coefficient, and the ordinal values with the help of the Spearman coefficient. The association coefficient takes values ranging from 0 to 1 . A value close to 0 indicates independence and the closer it gets to one, the stronger the relationship between the variables. The degree of correlation falls in the interval from -1 to +1 , the closer the value is to 1 or -1 , the stronger the relationship between the variables. Table 1 refers to the results that determine the strength of the correlation between variables (Mareš \& Rabušic, 2002).

TABLE 1: Correlation analysis results of survey data

\begin{tabular}{|c|c|c|c|c|c|c|c|c|c|}
\hline \multirow[b]{2}{*}{ Variable } & \multirow{2}{*}{$\begin{array}{l}\text { Frequency } \\
\text { of } \\
\text { information } \\
\text { searches }\end{array}$} & \multirow{2}{*}{$\begin{array}{c}\text { Information } \\
\text { search } \\
\text { location }\end{array}$} & \multirow{2}{*}{$\begin{array}{c}\text { Types of } \\
\text { searched } \\
\text { information }\end{array}$} & \multirow{2}{*}{$\begin{array}{c}\text { Information } \\
\text { retrieval } \\
\text { success }\end{array}$} & \multicolumn{5}{|c|}{ Frequency of use } \\
\hline & & & & & News & $\begin{array}{c}\text { Enter- } \\
\text { tainment }\end{array}$ & Education & Purchases & $\begin{array}{l}\text { Commu- } \\
\text { nication }\end{array}$ \\
\hline Age & 0.30 & 0.15 & 0.16 & 0.20 & 0.12 & 0.14 & 0.16 & 0.30 & 0.20 \\
\hline Gender & 0.05 & 0.08 & 0.16 & 0.06 & 0.12 & 0.05 & 0.12 & 0.08 & 0.20 \\
\hline Education & -0.11 & 0.11 & 0.17 & 0.10 & -0.23 & 0.06 & -0.20 & -0.10 & -0.10 \\
\hline $\begin{array}{l}\text { Social } \\
\text { status }\end{array}$ & 0.19 & 0.21 & 0.19 & 0.20 & 0.16 & 0.14 & 0.17 & 0.26 & 0.12 \\
\hline $\begin{array}{l}\text { Size of } \\
\text { household }\end{array}$ & 0.13 & 0.14 & 0.13 & 0.10 & 0.15 & 0.11 & 0.16 & 0.12 & 0.14 \\
\hline
\end{tabular}




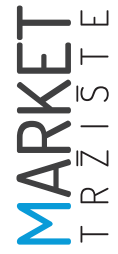

The dependence of age on the examined variables is low. There is a minor increased dependence of age on the frequency of Internet use and information retrieval success. Age has a more significant impact on the frequency of purchases and communication, which means that older seniors devote themselves more intensively to these activities. Gender does not affect the Internet use, as reflected in the given correlation. The more educated seniors are, the less they use the Internet; this means that the correlation coefficient shows independence between the respective variables. A small influence of the social status of the elderly can be noticed in the case of the type of information, retrieval success and frequency of searches as variables. People who are more than 55 years old are most likely to be unaffected by the size of their household in terms of their use of the Internet.

Based on the research results, we can refute a significant impact of demographic characteristics on the Internet use by seniors. The correlation coefficient indicates the relationship between the increasing age and the increasing frequency of Internet use for purchases and communication. Demographic characteristics, such as gender and number of household members, display very little or rather no dependence between relevant variables. In terms of education, it appears that people with a lower education use the Internet more often. But this is due to limited educational possibilities of the past era, when it was not common to have a university degree.

To determine the strongest influence of a variable on the Internet use, a decision tree was used, in which the main criterion selected was the location at which seniors use the Internet. The model shows that men use the Internet mainly at home or at work, and women in order to communicate. When examining conditionality between demographic variables and work on the Internet, we can talk about independence or little dependence to be more precise. This has to do with the fact that seniors of all ages use the Internet regardless of demographic factors; rather, it is more about social influences.

Based on the results of the survey and relationship modules, we can confirm the assumption that the level of education of the respondents and their status do not affect the types of information they search for online. Regarding the impact of age on the frequency of Internet use for a specific purpose, it is apparent that the elderly of all age groups have begun to use the Internet.

\section{CONCLUSION}

Advances in the Internet development for communication and shopping purposes, computer technology and the Internet availability have changed the way many people live, work and communicate. It is advisable that older people understand the positive effects that the Internet offers. They should be encouraged to use this medium to especially search for current information and updates, as well as to communicate within their social environment.

The aim of this research was to introduce the topic of 55+ people using the Internet by examining the influence of selected demographic characteristics. The research results show that some demographic variables have a rather insignificant impact on people's work with or use of the Internet.

Based on our market research results, we can state that they are in compliance with international studies. Older people are increasingly using the Internet and gradually their attitude towards this medium are changing as it becomes part of their lives - that goes particularly for the age group of 55-60 year olds. The results revealed that seniors use the Internet mainly at home; they connect to the Internet at least once per week, mainly to communicate and read online news. Shopping via e-shops is still not very popular among the older generation.

It should be noted that the number of seniors who use the Internet is gradually increasing. Se- 
niors are aware of the importance of using this medium, especially in obtaining new information about social events and communicating with other people. Their unwillingness to educate themselves in the world of digital media remains the biggest barrier to the use of the Internet.
Information technology experts have now realized that, with the increasing number of elderly people in the population, online services and products should be adapted to accommodate them. The Internet is already adapting to seniors, be it through the services it offers or through its content and ergonomics.

\section{References}

1. Australian Bureau of Statistics - ABS (2004). Measures of a knowledge-based economy and society, Australia. Available from: AusStats/abs@.nsf

2. Bosch, T., \& Currin, B. (2015). Uses and Gratifications of Computers in South African Elderly People. Comunicar, 45(23), 9-17.

3. Čevela, R., Čeledová, L., Kalvach, Z., Holčík, J., \& Kubů, P. (2014). Sociální gerontologie: Východiska ke zdravotní politice a podpoře zdravíve stář́. Praha: Grada Publishing.

4. Charakteristika Kraje (2015). Statistická ročenka Ústeckého kraje. Ústí nad Labem: Český statistický úřad. Available from: https://www.czso.cz/documents/10180/20549019/33008515chcz. pdf/73646aa3-27d8-4a00-99f8-a0632bde0fae?version=1.1

5. Clark, D. J. (2002). Older adults living through and with their computers. CIN: Computers, Informatics, Nursing, 20(3), 117-124.

6. Clow, K. E., \& Baack, D. (2008). Reklama, propagace a marketingová komunikace. Brno: Computer Press.

7. Demografické charakteristiky populace seniorů (2015). Český statistický úruad. Available from: https://www.czso.cz/documents/10180/20540365/3301431501.pdf/5bc99681-c872-4efd-84cece94710af5f1?version=1.5

8. Dvořáková, Š. (2007). Proč se soustředit na seniory? Available from: http://strategie.e15.cz/prilohy/ marketing-magazin/proc-se-soustredit-na-seniory

9. European Commission (2011a). Demography report 2010: Older, more numerous and diverse Europeans. European Union. Luxembourg: Publications Office of the European Union.

10. European Commission (2011b). EU e-inclusion site - Helping older people to access the Information Society. Available from: http://ec.europa.eu/digital-agenda/life-and-work

11. Eurostat (2015). Počet obyvatel podle věkových skupin. Available from: http://apl.czso.cz/pll/eutab/ html.h?ptabkod=tps00010

12. Fox, S. (2004). Older Americans and the Internet. Washington, DC: Pew Internet \& American Life Project.

13. Gatto, S. L., \& Tak, S. H. (2008). Computer, Internet, and E-Mail Use among Older Adults: Benefits and Barriers. Educational Gerontology, 34(9), 800-811.

14. Grimes, G. A. (2010). Older adults' knowledge of Internet hazards. Educational Gerontology, 36(3), 173-192.

15. Hanson, V. L. (2010). Influencing technology adoption by older adults. Interacting with Computers, 22(6), 502-509.

16. Katz, S., \& Marshall, B. (2003). New sex for old: lifestyle, consumerism, and the ethics of aging well. Journal of Aging Studies, 17(1), 3-16.

17. Lin, H-F. (2006). Understanding Behavioural Intention to Participate in Virtual Communities. CyberPsychology \& Behaviour, 9(5), 540-547. 
18. Mareš, P., \& Rabušic, L. (2002). Měření (síly) asociace mezi dvěma spojitými proměnnými: korelační koeficienty a graf. Brno: Masarykova Univerzita.

19. Ofcom (2010). Communications Market Report. Available from http://stakeholders.ofcom.org.uk/ market-data-research/market-data/communications-market-reports/cmr10/downloads/

20. Ogozalek, V. Z. (1991). The Social Impacts of Computing: Computer Technology and the Grayingof America. Social Science Computer Review, 9(4), 655-666.

21. Ruggiero, T. E. (2000). Uses and Gratifications Theory in the $21^{\text {st }}$ Century. Mass Communication \& Society, 3(1), 3-37.

22. Russell, C., Campbell, A., \& Hughes, I. (2008). Ageing, social capital and the Internet: Findings from an exploratory study of Australian 'silver surfers'. Australian Journal of Ageing, 27(2), 78-82.

23. Ryan, S. (2013). Older people need the Internet too. Available from: http://www.onlineopinion.com. au/view.asp?article $=15751$ \&page $=0$

24. Saboor, M., Sum, S., Sahaf, R., Sahaf, R., \& Pourghasem, M. (2015). The Internet use in elderly people. Medicinski Glasnik / Medical Gazette, 20(56), 43-52.

25. Sak, P., \& Kolesárová, K. (2012). Sociologie stárí a seniorů. Grada: Praha.

26. Seybert, H. (2012). Statistic in focus 50/2012: Internet use in households and by individuals in 2012. Eurostat. Available from: http://ec.europa.eu/eurostat/documents/3433488/5585460/KSSF-12-050-EN.PDF/39000dab-e2b7-49b2-bc4b-6aad0bf01279

27. Shapira, N., Barak, A., \& Gal, I. (2007). Promoting older adults' wellbeing through Internet training and use. Aging and Mental Health, 11(5), 477-484.

28. Smith, A. (2014). Internet and broadband adoption rates among seniors are steadily increasing, but still well below the national average. Pew Research Center. Available from: http://www.pewInternet.org/2014/04/03/usage-and-adoption/

29. Śniadek, J. (2006). Age of seniors - a challenge for tourism and lemure industry. Studies in physical culture and tourism, 13, 103-105.

30. StatCounter (2017). Search Engine Market Share in Czech Republic. Available from: http://gs.statcounter.com/search-engine-market-share/all/czech-republic/\#yearly-2010-2017

31. Sum, S., Mathews, M., Hughes, I., \& Campbell, A. (2008). Internet Use and Loneliness in Older Adults. CyberPsychology \& Behavior, 11(2), 208-211.

32. TopList (2017). Historie. Available from: https://www.toplist.cz/stat/?a=history\&type=4

33. Twigg, J. (2004). The body, gender, and age: feminist insights in social gerontology. Journal of Aging Studies, 18(1), 59-73.

34. Ward, R. (2013). Change in perceived age in middle and later life. International Journal of Aging \& Human Development, 76(3), 251-267.

35. Westerhof, G., Barrett, A., \& Steverink, N. (2003). Forever young? A comparison of age identities in the United States and Germany. Research of Aging, 25(4), 366-383.

36. Westerhof, G. J., Harink, K., Van Selm, M., Strick, M., \& Van Baaren, R. (2010). Filling a missing link: the influence of portrayals of older characters in television commercials on the memory performance of older adults. Ageing and Society, 30(6), 987-1009.

37. White, H., McConnell, E., Branch, L. G., Sloane, R., Pieper, C., \& Box, T. L. (2002). A randomized controlled trial of the psychosocial impact of providing Internet training and access to older adults. Aging \& Mental Health, 6(3), 213-221.

38. World Health Organisation (2014). Facts about ageing. Available from: http://www.who.int/ageing/about/facts/en/.

39. Wright, K. (2000). Computer-mediated social support, older adults, and coping. Journal of Communication, 50(3), 100-118. 